\title{
Effect of Very Small Concentrations of Insulin on Forearm Metabolism. Persistence of Its Action on Potassium and Free Fatty Acids without Its Effect on Glucose *
}

\author{
Kenneth L. Zierler and David Rabinowitz $\dagger$ \\ (From the Department of Medicine, The Johns Hopkins University and Hospital, \\ Baltimore, $M d$.)
}

When insulin is infused into a brachial artery of normal men at a constant rate of $100 \mu \mathrm{U}$ per minute per $\mathrm{kg}$ of body weight, there appears rapidly evidence of increased glucose uptake by forearm muscles and by forearm adipose tissue, a shift from net potassium loss to potassium uptake by muscle, increased $\mathrm{K}$ uptake by adipose tissue, and marked decrease in release of free fatty acids (FFA) by forearm adipose tissue $(1,2)$. When insulin is infused at the same rate into a brachial artery of patients with active acromegaly, into normal men in whom endogenous growth hormone activity has been increased by a 3-day fast, or into normal men simultaneously with human growth hormone (HGH) in the same syringe, there is evidence of less than the normal response to insulin with respect to glucose uptake by forearm muscles and by forearm adipose tissue (3-7). In every instance, however, the response with respect to FFA release was at least as great as that occurring in normal men to whom only insulin was exhibited. Interpretation of the combined effect of $\mathrm{HGH}$ and insulin on $\mathrm{K}$ uptake is com-

* Submitted for publication July 1, 1963; accepted January 8, 1964.

These studies were supported by U. S. Public Health Service research grants AM 00750 and AM 05524 and graduate training grant 2A-5232, National Institute of Arthritis and Metabolic Diseases, and by a grant-in-aid from the Muscular Dystrophy Associations of America, Inc.

Presented to the Seventy-sixth Annual Meeting of the Association of American Physicians.

A summary of the results of these experiments has been incorporated in a synthesizing review : Roles of insulin and growth hormone, based on studies of forearm metabolism in man. Medicine 1963, 42, 385.

$\dagger$ The work was done during the tenure of an Established Investigatorship of the American Heart Association. plicated by the fact that either agent alone promotes translocation of $\mathrm{K}$ into forearm tissues. However, the combined effect of the two hormones on $\mathrm{K}$ uptake was not additive and, indeed, was intermediate between the effects of insulin alone and of $\mathrm{HGH}$ alone under conditions in which insulin alone translocated more $\mathrm{K}$ than did $\mathrm{HGH}$.

It occurred to us that the combination of $\mathrm{HGH}$ and insulin might behave toward glucose and $\mathrm{K}$ uptake by muscle and adipose tissue and toward FFA release from adipose tissue like a smaller dose of insulin alone. If this were true, the effects of insulin on FFA release and on $\mathrm{K}$ uptake could be observed with a concentration of insulin too small to provoke glucose uptake by either muscle or adipose tissue.

Accordingly, to add to our experience of infusing $100 \mu \mathrm{U}$ per minute per kg body weight intra-arterially, we examined the effects of constant intra-arterial infusion at two smaller rates, $1 \mu \mathrm{U}$ and $10 \mu \mathrm{U}$ per minute per $\mathrm{kg}$ of body weight. When these infusates are diluted in the brachial artery by blood flowing past the site of injection, concentration of insulin in plasma entering the forearm is elevated by approximately $4 \mu \mathrm{U}$ per $\mathrm{ml}, 40 \mu \mathrm{U}$ per $\mathrm{ml}$, and, for the largest dose reported previously, $400 \mu \mathrm{U}$ per $\mathrm{ml}$.

Infusion of insulin at the smallest rate produced no effect on forearm metabolism as we are able to estimate it. Infusion of insulin at the medium rate produced effects on $\mathrm{K}$ uptake and on FFA release that were approximately half as great or as great as those produced by the largest rate of infusion but failed to produce an effect on glucose uptake distinguishable by our methods of analysis. We wish to report the observations on which these statements rest and to indicate some implications of the results. 


\section{Methods}

Subjects were nine healthy young men with normal dietary histories of carbohydrate intake. No food was permitted after $8 \mathrm{p} . \mathrm{m}$. on the evening preceding the experiment. Studies were made between 9 a.m. and 1 p.m., that is, 13 to 17 hours after the last meal. Catheters were placed in a brachial artery, an ipsilateral deep vein $(\mathrm{dv})$ ) draining mostly muscle (but undoubtedly also the adipose tissue mingling with muscle), and an ipsilateral superficial vein (sv) draining mostly, but not exclusively, skin and subcutaneous adipose tissue. Circulation to the wrist and hand was excluded during experimental periods by a sphygmomanometer cuff inflated well beyond systolic pressure. Blood flow was measured by the constant injection indicator-dilution method. Sets of arterial, dv, and sv samples were collected simultaneously at intervals before, during, and after infusion of insulin. Details of these procedures have been described $(1,8,9)$.

If blood flow is constant, as it was in our experiments, changes in arterio-deep venous ( $a-d v$ ) concentration differences in glucose and $\mathrm{K}$ are, in the main, a measure of changes in uptake or output of glucose and $\mathrm{K}$ by forearm muscle; changes in arterio-superficial venous (a-sv) concentration differences in glucose, $\mathrm{K}$, and FFA probably measure mostly changes in uptake or output of these substances by adipose tissue of the forearm. Arteriodeep venous concentration differences in FFA reflect the sum of two effects, the uptake of FFA by forearm muscle and the output of FFA by adipose tissue mixed with muscle bundles (9). Insulin is thought to have no effect on uptake of FFA by muscle, although the issue is unproved, so that changes in a-dv in FFA produced by insulin probably represent changes in release of FFA from intermuscular adipose tissue (2).

Glucagon-free insulin 1 was injected intra-arterially for either 26 minutes ( 6 subjects) or 35 minutes ( 3 subjects) at a rate delivering $10 \mu \mathrm{U}$ of insulin per minute per $\mathrm{kg}$ body weight. Five subjects also received one or the other of these lots of insulin intra-arterially for 26 minutes at a rate that delivered $1 \mu \mathrm{U}$ of insulin per minute per $\mathrm{kg}$ body weight.

Glucose was determined by a glucose oxidase method, $\mathrm{K}$ by internal standard flame photometry, and FFA by a modified Dole extraction and titration method (9).

\section{Results}

Insulin concentration delivered to forearm. The increase in arterial plasma insulin concentration beyond the endogenous concentration, produced by a constant intra-arterial infusion, is the rate of injection (microunits per minute) divided by arterial plasma flow (milliliters per minute)-

${ }^{1}$ Lot W 3606 in 3 subjects and lot W 3691 in 6, a gift of Eli Lilly and Co., Indianapolis, Ind., through Dr. W. R. Kirtley, to whom we are indebted.
TABLE I

\begin{tabular}{lccc}
\multicolumn{4}{c}{$\begin{array}{c}\text { Estimated enrichment of local arterial } \\
\text { insulin concentration* }\end{array}$} \\
\hline & \multicolumn{3}{c}{ Time in minutes after insulin } \\
\cline { 2 - 4 } \cline { 2 - 3 } Subject & $12-18$ & $19-35$ & Mean \\
\hline & $\mu U / m l$ & $\mu U / m l$ & $\mu U / m l$ \\
J.M.T. & 22.8 & 25.6 & 24.3 \\
D.S. & 26.8 & 24.5 & 25.7 \\
J.C. & 30.9 & 28.3 & 29.6 \\
W.C. & 37.4 & 28.0 & 31.8 \\
T.M. & 32.6 & 36.9 & 34.7 \\
L.S. & 28.7 & 43.7 & 36.2 \\
D.G. & 49.0 & 45.5 & 46.9 \\
D.H. & 45.5 & 53.7 & 50.3 \\
H.W. & 70.5 & 60.2 & 65.3 \\
M. & 38.2 & 38.5 & 38.3 \\
& & & \\
\hline
\end{tabular}

* Values are obtained by dividing the known rate of injection of insulin $(10 \mu \mathrm{U}$ per minute per $\mathrm{kg})$ by total forearm plasma flow. In 6 subjects plasma flow was measured once during the 12 to 18 minutes of insulin infusion and once during the 19 to 26 minutes. In the remaining 3 subjects (D.H., D.G., and W.C.) plasma flow was measured at 12,18,26, 30, and 35 minutes after the start of insulin. In these subjects, plasma insulin levels at 12 to 18 and 19 to 35 minutes are the means of two and three values, respectively.

assuming no loss of insulin by binding to apparatus, vessel walls, or blood cells and assuming that injected insulin is diluted evenly by arterial plasma flowing past the injection site. When $1 \mu \mathrm{U}$ of insulin was injected per minute per $\mathrm{kg}$ of body weight, arterial plasma insulin concentration increased on the average by $3 \mu \mathrm{U}$ per $\mathrm{ml}$. When 10 $\mu \mathrm{U}$ of insulin was injected per minute per $\mathrm{kg}$ of body weight, the mean increase in arterial plasma insulin was $38 \mu \mathrm{U}$ per $\mathrm{ml}$ (Table $\mathrm{I}$ ). In a similar group of 4 of our subjects (10) under similar conditions ( 15 hours postprandial, mid-morning, resting), endogenous arterial insulin concentration, measured by radioimmunoassay, was $9 \mu \mathrm{U}$ per $\mathrm{ml}$ (range, 5 to 11.5 ).

Lack of systemic effect. In interpreting these experiments, it is essential to know that our maneuvers did not alter arterial concentrations of metabolites. Changing arterial concentrations make absolutely invalid the use of simultaneous a-v concentration differences to estimate metabolism, and changes in arterial concentration of certain substances may also provoke counterregulatory devices that may exert their own effects on forearm metabolism. There were no changes in arterial concentration of glucose, $\mathrm{K}$, or FFA before, during, or after infusion of insulin, just as 
TABLE II

Effect of intra-arterial insulin (10 $\mu \mathrm{U}$ per $\mathrm{kg}$ per minute)

\begin{tabular}{|c|c|c|c|c|c|c|c|c|c|c|}
\hline \multirow[b]{4}{*}{ Subject } & \multicolumn{6}{|c|}{ a-dv glucose } & \multicolumn{4}{|c|}{ a-dv potassium } \\
\hline & \multirow[b]{3}{*}{ Basal } & \multirow{2}{*}{\multicolumn{3}{|c|}{$\begin{array}{l}\text { Time in minutes } \\
\text { after insulin }\end{array}$}} & \multicolumn{2}{|c|}{ Change in a-dv glucose } & \multirow[b]{3}{*}{ Basal } & \multirow{2}{*}{\multicolumn{3}{|c|}{ Time in minutes after insulin }} \\
\hline & & & & & \multirow{2}{*}{$\begin{array}{l}\text { Insulin } \\
\text { mean } \\
\text { minus } \\
\text { basal } \\
\text { mean }\end{array}$} & \multirow{2}{*}{$\begin{array}{c}\text { Insulin } \\
(19-35) \\
\text { minus } \\
\text { basal } \\
\text { mean }\end{array}$} & & & & \\
\hline & & $12-18$ & $19-35$ & Mean & & & & $12-18$ & 19-35 & Mean \\
\hline & $\mu \mathrm{mole} / \mathrm{ml}$ & $\mu \mathrm{mole} / \mathrm{ml}$ & $\mu m o l e / m l$ & $\mu m o l e / m l$ & $\mu m o l e / m l$ & $\mu m o l e / m l$ & $\mu m o l e / m l$ & $\mu m o l e / m l$ & $\mu m o l e / m l$ & $\mu m o l e / m l$ \\
\hline H.W. & 0.34 & 0.36 & 0.54 & 0.45 & +0.11 & +0.21 & -0.02 & +0.05 & +0.12 & +0.08 \\
\hline L.S. & 0.17 & 0.26 & 0.31 & 0.28 & +0.10 & +0.14 & -0.12 & +0.07 & +0.07 & +0.07 \\
\hline T.M. & 0.43 & 0.49 & 0.56 & 0.52 & +0.10 & +0.13 & -0.30 & 0 & +0.11 & +0.05 \\
\hline J.M.T. & 0.05 & 0.23 & 0.16 & 0.19 & +0.14 & +0.11 & -0.10 & -0.15 & -0.20 & -0.18 \\
\hline W.C. & 0.26 & 0.26 & 0.30 & 0.28 & +0.03 & +0.04 & -0.03 & +0.13 & +0.23 & +0.19 \\
\hline J.C. & 0.20 & 0.14 & 0.21 & 0.18 & -0.02 & +0.01 & -0.11 & -0.10 & +0.10 & 0 \\
\hline D.H. & 0.31 & 0.25 & 0.29 & 0.28 & -0.03 & -0.02 & -0.04 & +0.09 & +0.08 & +0.08 \\
\hline D.G. & 0.38 & 0.40 & 0.32 & 0.35 & -0.03 & -0.06 & +0.08 & +0.08 & +0.25 & +0.18 \\
\hline D.S. & 0.35 & 0.33 & 0.25 & 0.29 & -0.06 & -0.10 & +0.11 & +0.17 & +0.18 & +0.17 \\
\hline Mean & 0.28 & 0.30 & 0.33 & 0.31 & 0.04 & 0.05 & -0.06 & +0.04 & +0.10 & +0.07 \\
\hline $\pm 1 \mathrm{SEM}$ & 0.037 & 0.036 & 0.046 & 0.035 & 0.025 & 0.034 & 0.038 & 0.035 & 0.040 & 0.036 \\
\hline p & & NSa & NSb & NSe & $\mathrm{NS}^{\mathrm{d}}$ & NSe & & $<0.05^{\mathrm{a}}$ & $<0.01^{b}$ & $<0.02^{\mathrm{c}}$ \\
\hline
\end{tabular}

$* \mathrm{a}-\mathrm{dv}=$ arterio-deep venous concentration; $\mathrm{SEM}=$ standard error of the mean. All values in Tables II and III have been calculated to two decimal places beyond those listed in the table for the statistical computations and for the derived data; this dropping of two numbers is the ex-

planation for what appear to be minor discrepancies at some points.
Mean basal values are the means of three or more sets of samples in 8 subjects. Only one set of basal a-dv differences was obtained in subject L.S. There was an average of one sample per subject during the 12- to 18-minute insulin period and two samples per subject during the 19- to 35-minute insulin period.

Statistical analyses in Tables II and III were performed with the $t$ test. In the case of superscripts a, b, and c, the mean value obtaining at that time was tested against the mean basal value. In the case of superscripts $d$ and e, paired analyses were performed. NS refers to $p>0.05$.

there were none with infusion of the largest dose, described previously $(1,2)$.

Plasma flow. That plasma flow be stable during the experiment is important if metabolism is to be assessed accurately; in our experiments the flow was acceptably stable. In 5 subjects, during insulin infusion the greatest variation in flow was $7 \%$ from the subject's mean flow. In the remaining 4 subjects, one flow determination differed from the subject's mean flow by more than $20 \%$. Mean plasma flow for the 9 subjects was $1.9 \mathrm{ml}$ per minute per $100 \mathrm{ml}$ forearm during the control

TABLE III

Effect of intra-arterial insulin (10 $\mu U$ per $k g$ per minute)

\begin{tabular}{|c|c|c|c|c|c|c|c|c|c|c|}
\hline \multirow[b]{4}{*}{ Subject } & \multicolumn{6}{|c|}{ a-sv glucose } & \multicolumn{4}{|c|}{ a-sv potassium } \\
\hline & \multirow[b]{3}{*}{ Basal } & \multirow{2}{*}{\multicolumn{3}{|c|}{$\begin{array}{l}\text { Time in minutes } \\
\text { after insulin }\end{array}$}} & \multicolumn{2}{|c|}{ Change in a-sv glucose } & \multirow[b]{3}{*}{ Basal } & \multirow{2}{*}{\multicolumn{3}{|c|}{ Time in minutes after insulin }} \\
\hline & & & & & \multirow{2}{*}{$\begin{array}{c}\text { Insulin } \\
\text { mean } \\
\text { minus } \\
\text { basal } \\
\text { mean }\end{array}$} & \multirow{2}{*}{$\begin{array}{c}\text { Insulin } \\
(19-35) \\
\text { minus } \\
\text { basal } \\
\text { mean }\end{array}$} & & & & \\
\hline & & $12-18$ & $19-35$ & Mean & & & & $12-18$ & $19-35$ & Mean \\
\hline & $\mu m o l e / m l$ & \multicolumn{3}{|c|}{ 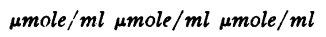 } & $\mu m o l e / m l$ & $\mu m o l e / m l$ & $\mu m o l e / m l$ & $\mu m o l e / m l$ & $\mu \mathrm{mole} / \mathrm{ml}$ & $\mu m o l e / m l$ \\
\hline H.W. & 0.32 & 0.28 & 0.43 & 0.36 & +0.03 & +0.11 & +0.10 & +0.13 & +0.13 & +0.13 \\
\hline L.S. & 0.07 & & 0.45 & 0.45 & +0.38 & +0.38 & -0.28 & & +0.12 & +0.12 \\
\hline T.M. & 0.42 & 0.43 & 0.56 & 0.50 & +0.08 & +0.14 & -0.39 & -0.16 & +0.01 & -0.08 \\
\hline J.M.T. & 0.08 & 0.24 & 0.10 & 0.17 & +0.09 & +0.03 & -0.06 & +0.02 & +0.04 & +0.03 \\
\hline W.C. & 0.27 & 0.29 & 0.28 & 0.28 & +0.01 & +0.01 & -0.06 & +0.06 & +0.02 & +0.04 \\
\hline J.C. & 0.32 & 0.26 & 0.29 & 0.28 & -0.04 & -0.02 & -0.07 & +0.01 & 0 & $\mathbf{0}$ \\
\hline D.H. & 0.28 & 0.24 & 0.36 & 0.27 & -0.01 & +0.08 & +0.05 & +0.23 & +0.24 & +0.24 \\
\hline D.G. & 0.37 & 0.27 & 0.39 & 0.35 & -0.02 & +0.02 & +0.13 & +0.10 & +0.22 & +0.17 \\
\hline D.S. & 0.37 & 0.20 & 0.27 & 0.23 & -0.14 & -0.10 & +0.17 & +0.14 & +0.21 & +0.18 \\
\hline Mean & 0.28 & 0.28 & 0.35 & 0.32 & +0.04 & +0.07 & -0.04 & +0.07 & +0.11 & +0.09 \\
\hline $\pm 1 \mathrm{SEM}$ & 0.040 & 0.025 & 0.044 & 0.032 & 0.043 & 0.046 & 0.059 & 0.042 & 0.037 & 0.032 \\
\hline $\mathrm{p}$ & & $\mathrm{NS}^{\mathrm{a}}$ & $N^{\top} S^{b}$ & NSe & $\mathrm{NS}^{d}$ & $\mathrm{NS}^{\mathrm{e}}$ & & $\mathrm{NS}^{\mathrm{a}}$ & $<0.025^{b}$ & $<0.03^{\circ}$ \\
\hline
\end{tabular}

*a-sv = arterio-superficial venous concentration. Mean basal values are the means of three or more sets of samples in 7 subjects. Three sets of a-sv glucose and FFA and two sets of a-sv $\mathrm{K}$ were obtained in subject D.H. Two sets of a-sv FFA and one set of a-sv glucose and $\mathrm{K}$ were obtained in subject L.S. Statistical analyses as in Table II : superscripts a, b, and c refer to grouped tests of significance; superscripts d and e refer to paired tests of significance. 
TABLE II

on a-dv glucose, potassium, and free fatty acid differences*

\begin{tabular}{|c|c|c|c|c|c|c|c|}
\hline \multirow{2}{*}{\multicolumn{2}{|c|}{$\begin{array}{c}\text { a-dv potassium } \\
\text { Change in a-dv } K\end{array}$}} & \multicolumn{6}{|c|}{ a-dv FFA } \\
\hline & & \multirow[b]{3}{*}{ Basal } & \multirow{2}{*}{\multicolumn{3}{|c|}{ Time in minutes after insulin }} & \multicolumn{2}{|c|}{ Change in a-dv FFA } \\
\hline \multirow{2}{*}{$\begin{array}{c}\text { Insulin } \\
\text { mean } \\
\text { minus } \\
\text { basal } \\
\text { mean }\end{array}$} & \multirow{2}{*}{$\begin{array}{c}\text { Insulin } \\
(\mathbf{1 9 - 3 5 )} \\
\text { minus } \\
\text { basal } \\
\text { mean }\end{array}$} & & & & & \multirow{2}{*}{$\begin{array}{c}\text { Insulin } \\
\text { mean } \\
\text { minus } \\
\text { basal } \\
\text { mean }\end{array}$} & \multirow{2}{*}{$\begin{array}{c}\text { Insulin } \\
(\mathbf{1 9 - 3 5}) \\
\text { minus } \\
\text { basal } \\
\text { mean }\end{array}$} \\
\hline & & & $12-18$ & $19-35$ & Mean & & \\
\hline$\mu m o l e / m l$ & $\mu m o l e / m l$ & $\mu m o l e / m l$ & $\mu m o l e / m l$ & $\mu m o l e / m l$ & $\mu \mathrm{mole} / \mathrm{ml}$ & $\mu m o l e / m l$ & $\mu m o l e / m l$ \\
\hline+0.10 & +0.13 & +0.01 & -0.03 & +0.03 & $\mathbf{0}$ & -0.01 & +0.02 \\
\hline+0.19 & +0.19 & -0.02 & +0.02 & +0.19 & +0.08 & +0.10 & +0.21 \\
\hline+0.35 & +0.40 & -0.13 & -0.10 & -0.12 & -0.11 & +0.02 & +0.01 \\
\hline-0.08 & -0.10 & -0.17 & +0.09 & -0.03 & +0.03 & +0.20 & +0.15 \\
\hline+0.22 & +0.26 & -0.08 & -0.19 & +0.03 & -0.06 & +0.02 & +0.12 \\
\hline+0.10 & +0.20 & -0.21 & -0.04 & -0.08 & -0.06 & +0.16 & +0.13 \\
\hline+0.12 & +0.12 & -0.17 & -0.02 & -0.07 & -0.05 & +0.12 & +0.09 \\
\hline+0.10 & +0.16 & -0.13 & -0.08 & -0.01 & -0.04 & +0.09 & +0.12 \\
\hline+0.06 & +0.06 & -0.04 & -0.04 & +0.02 & -0.01 & +0.03 & +0.06 \\
\hline+0.13 & +0.16 & -0.10 & -0.04 & 0 & -0.02 & +0.08 & +0.10 \\
\hline 0.037 & 0.046 & 0.025 & 0.026 & 0.030 & 0.019 & 0.024 & 0.021 \\
\hline$<0.005^{d}$ & $<0.01^{e}$ & & NSa & $<0.025^{b}$ & $<0.03^{\circ}$ & $<0.005^{d}$ & $<0.001^{\bullet}$ \\
\hline
\end{tabular}

period, $1.9 \mathrm{ml}$ per minute during the period 12 to 18 minutes after insulin started, and $1.8 \mathrm{ml}$ per minute during the remainder of the insulin infusion.

Lack of effect of smaller dose of insulin. Intra-arterial infusion of $1 \mu \mathrm{U}$ of insulin per minute per $\mathrm{kg}$ of body weight produced no change in a-dv or a-sv of glucose, $\mathrm{K}$, or FFA. If this small increment in insulin concentration has any metabolic effect with respect to these substances, it is beyond the resolution of our methods.

Effect of $10 \mu U$ per minute per $k g$ of body weight. Results appear in Tables II and III.

Arteriovenous differences in the basal state. Since the responses of these 9 subjects are to be compared with those of the group of subjects to whom ten times this concentration of insulin had been administered, it is important to examine ways

TABLE III

on a-sv glucose, potassium, and free fatty acid differences*

\begin{tabular}{|c|c|c|c|c|c|c|c|}
\hline \multirow{2}{*}{\multicolumn{2}{|c|}{$\begin{array}{c}\text { a-sv potassium } \\
\text { Change in a-sv } K\end{array}$}} & \multicolumn{6}{|c|}{ a-sv FFA } \\
\hline & & \multirow[b]{3}{*}{ Basal } & \multirow{2}{*}{\multicolumn{3}{|c|}{ Time in minutes after insulin }} & \multicolumn{2}{|c|}{ Change in a-sv FFA } \\
\hline \multirow{2}{*}{$\begin{array}{c}\text { Insulin } \\
\text { mean } \\
\text { minus } \\
\text { basal } \\
\text { mean }\end{array}$} & \multirow{2}{*}{$\begin{array}{c}\text { Insulin } \\
(19-35) \\
\text { minus } \\
\text { basal } \\
\text { mean }\end{array}$} & & & & & \multirow{2}{*}{$\begin{array}{c}\text { Insulin } \\
\text { mean } \\
\text { minus } \\
\text { basal } \\
\text { mean }\end{array}$} & \multirow{2}{*}{$\begin{array}{c}\text { Insulin } \\
(19-35) \\
\text { minus } \\
\text { basal } \\
\text { mean }\end{array}$} \\
\hline & & & $12-18$ & 19-35 & Mean & & \\
\hline$\mu m o l e / m l$ & $\mu m o l e / m l$ & $\mu m o l e / m l$ & umole $/ \mathrm{ml}$ & $\mu m o l e / m l$ & $\mu m o l e / m l$ & umole $/ m l$ & $\mu m o l e / m l$ \\
\hline+0.02 & +0.02 & -0.05 & -0.06 & -0.03 & -0.04 & +0.01 & +0.02 \\
\hline+0.40 & +0.40 & -0.12 & & +0.13 & +0.13 & +0.24 & +0.24 \\
\hline+0.32 & +0.40 & -0.10 & -0.12 & -0.12 & -0.12 & -0.02 & -0.02 \\
\hline+0.09 & +0.10 & -0.08 & +0.12 & +0.11 & +0.12 & +0.19 & +0.18 \\
\hline+0.10 & +0.08 & -0.29 & -0.17 & -0.06 & -0.10 & +0.19 & +0.24 \\
\hline+0.07 & +0.07 & -0.16 & +0.04 & +0.03 & +0.03 & +0.19 & +0.18 \\
\hline+0.19 & +0.20 & -0.27 & -0.07 & -0.14 & -0.12 & +0.15 & +0.12 \\
\hline+0.04 & +0.08 & -0.26 & +0.04 & 0 & +0.02 & +0.28 & +0.26 \\
\hline+0.01 & +0.04 & -0.10 & -0.03 & -0.05 & -0.04 & +0.06 & +0.06 \\
\hline+0.14 & +0.16 & -0.16 & -0.03 & -0.02 & -0.02 & +0.14 & +0.14 \\
\hline 0.044 & 0.048 & 0.032 & 0.034 & 0.031 & 0.032 & 0.035 & 0.035 \\
\hline$<0.01^{d}$ & $<0.01^{e}$ & & $<0.01^{\mathrm{a}}$ & $<0.005^{b}$ & $<0.005^{\circ}$ & $<0.005^{d}$ & $<0.005^{e}$ \\
\hline
\end{tabular}




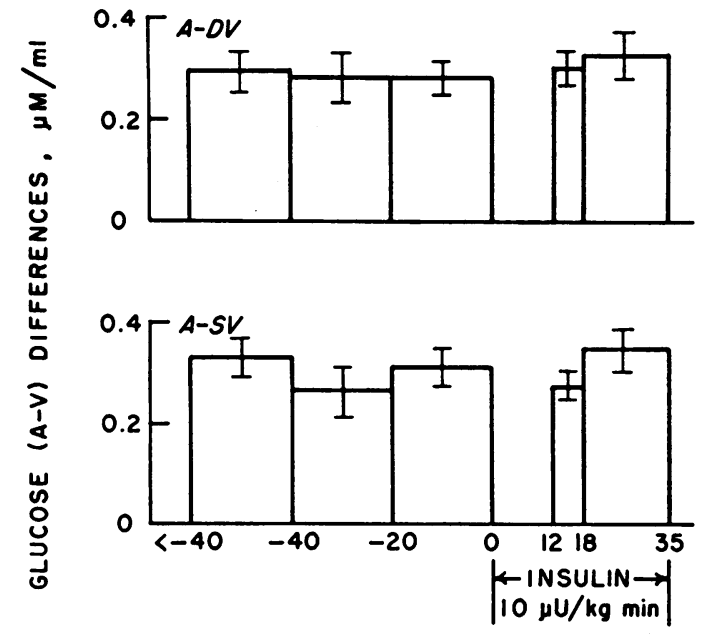

MINUTES AFTER START OF INTRA-ARTERIAL INSULIN

Fig. 1. LACK OF EFFECT OF INTRA-ARTERIAL INSULIN ON GLUCOSE A-V DIFFERENCES IN 9 NORMAL SUBJECTS. Each rectangle represents mean ( \pm 1 standard error of mean, SEM) of a-v concentration differences occurring during the time interval indicated. Data to left of time zero illustrate spontaneous variation in glucose a-v differences, indistinguishable from those found during insulin infusion. Upper section, a-dv (arterio-deep venous) glucose concentration differences; lower section, a-sv (arterio-superficial venous).

in which the two sets of experiments may have differed. For this purpose data obtained during the pre-insulin period are compared. Arterio-su perficial venous concentration differences in glucose, $\mathrm{K}$, and FFA were similar in the two groups of subjects, so that quantitative comparisons can be made from changes in a-sv differences produced during infusion of the two concentrations of insulin. However, basal a-dv glucose differences were larger, $\mathrm{K}$ differences were less negative, and FFA differences were more negative than among normal subjects in whom we have made these measurements previously. There are several possible explanations for this. This is the metabolic pattern to be expected a few hours earlier in the morning than the time when most of our previous observations were made, and it is the concentration profile produced by contamination or drainage of superficial venous blood into the deep vein sampled. Whatever the explanation, this complicates comparison of insulin effect on glucose $\mathrm{a}-\mathrm{dv}$ and on $\mathrm{K} \mathrm{a}-\mathrm{dv}$, but it does not vitiate it, as will be indicated at the proper time.
Glucose. No matter how the data were analyzed-whether by comparing pooled a-dv (or a-sv) differences for all subjects before insulin to pooled a-dv (or a-sv) differences during insulin infusion, or by examining whether or not the change in a-dv (or a-sv) differences, using each subject as his own control, was different from zero-it was impossible to demonstrate that this dose of insulin affected glucose a-v differences (Figures 1 and 2). We could not show that this dose of insulin was associated with translocation of glucose by either forearm muscle or adipose tissue.

Potassium. For tissues drained by $\mathrm{dv}$ and for those drained by sv, $10 \mu \mathrm{U}$ per minute of insulin exerted an effect on $\mathrm{K}$ movement (Figure 3 ). Maximal change in a-sv difference in response to $10 \mu \mathrm{U}$ per minute of insulin was about $60 \%$ of that in response to $100 \mu \mathrm{U}$ per minute. We have already noted that $\mathrm{K}$ a-dv differences during the control period were less negative than in our earlier experience. This difference in initial conditions complicates comparison of the effect of the two rates of infusion of insulin because the response to insulin at either dose depends on the initial a-v difference (Figure 4); that is, the

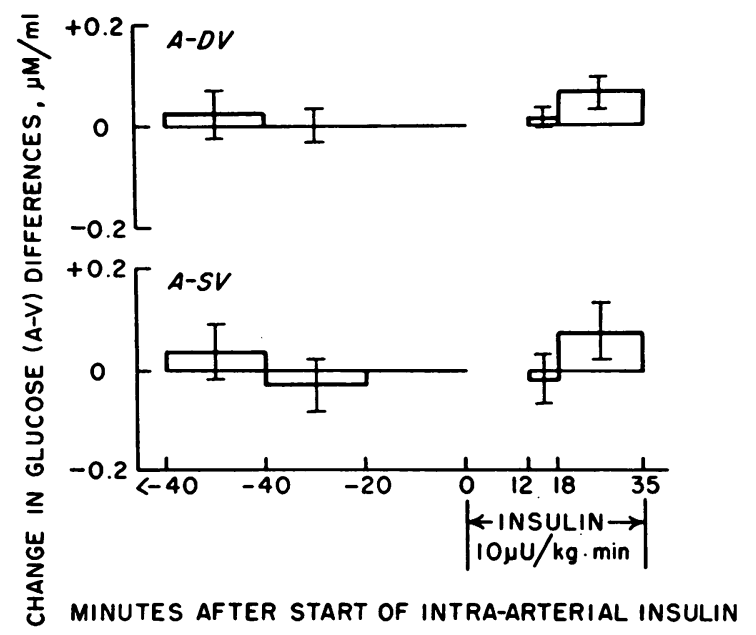

Fig. 2. LACK OF EFFECT OF INTRA-ARTERIAL INSULIN on GLUCOSE A-v Differences. Data on same 9 subjects shown in Figure 1 have been regrouped to pair subjects' pre-and postinsulin glucose a-v differences. Each rectangle represents mean $( \pm 1$ SEM) of the change in $a-v$ difference in each subject compared to his a-v difference during the 20 -minute interval immediately before insulin infusion. 
maximal a-v difference in $\mathrm{K}$ reached in response to insulin tends to be the same in all subjects, so that the change in a-v difference is a linear function of initial a-v difference. Over the range at which initial a-v differences were the same in the two groups of subjects, $10 \mu \mathrm{U}$ per minute of insulin was two-thirds to three-fourths as effective on $\mathrm{K}$ as was $100 \mu \mathrm{U}$ per minute. When no allowance is made for differences in initial conditions, the smaller dose of insulin produced a change in a-v difference that was one-third as great as that produced by ten times that dose.

Free fatty acids. Infusion of insulin, $10 \mu \mathrm{U}$ per minute, decreased $\mathrm{dv}$ and $\mathrm{sv}$ concentrations of FFA until both equaled arterial FFA concentration. This dose of insulin altered a-v FFA differences significantly (Figure 5). The change in a-sv differences was about $60 \%$ of that produced

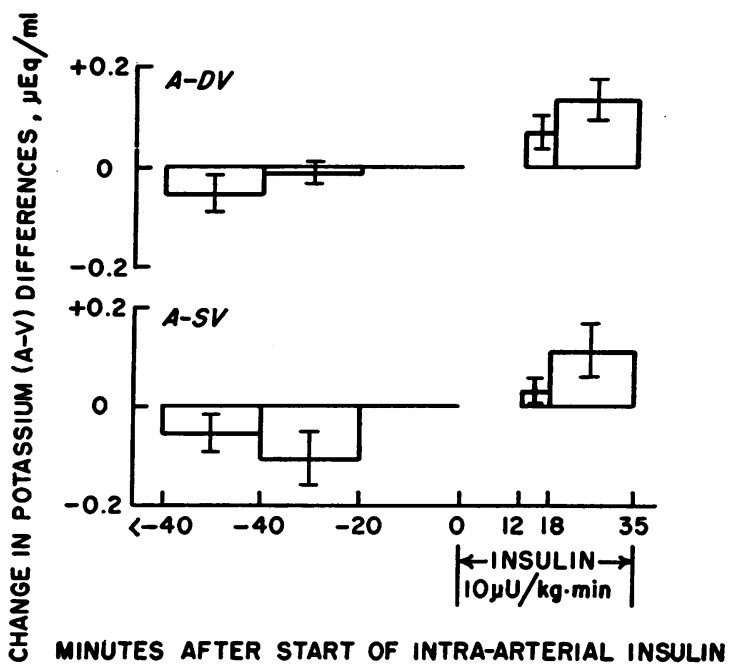

Fig. 3. EFFECT OF INTRA-ARTERIAL INSULIN A-V DIFFERENCES AMONG 9 NORMAL SUBJECTS. Data plotted as in Figure 2.

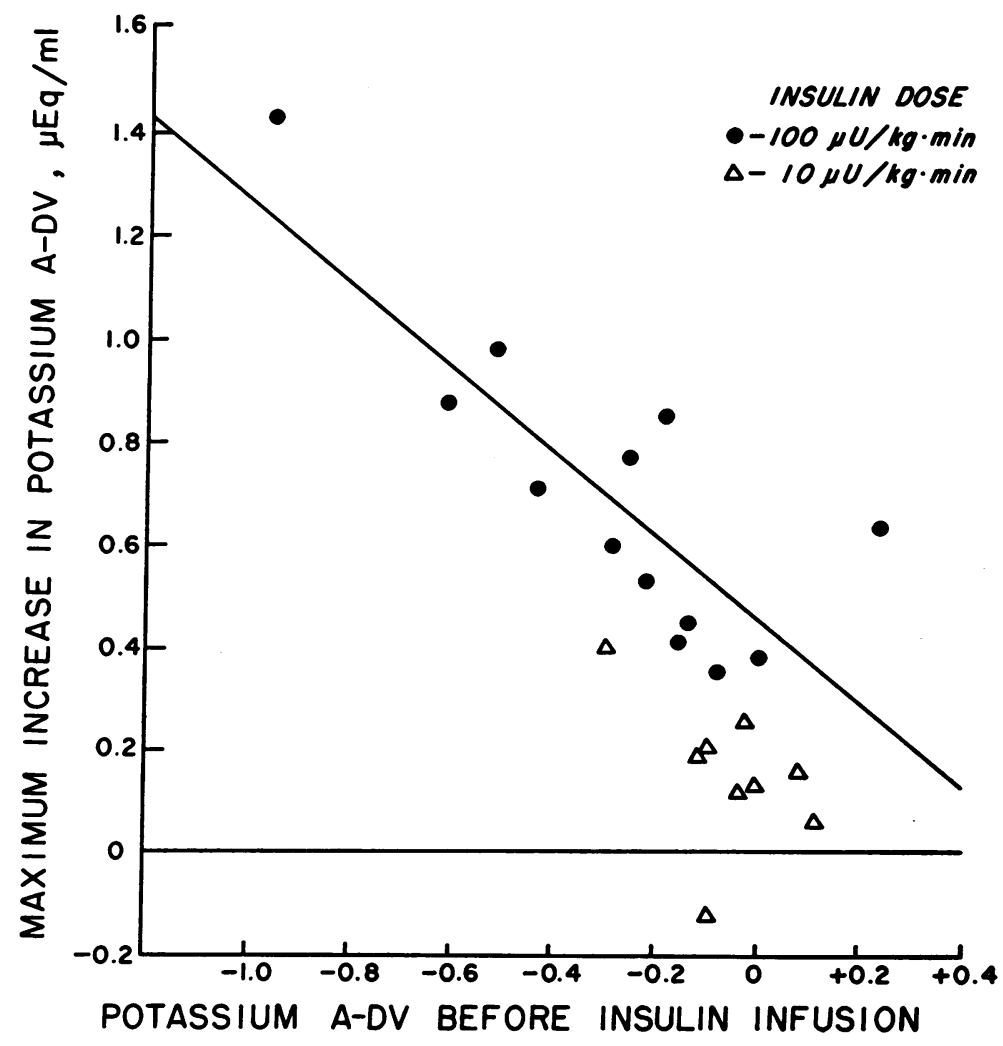

Fig. 4. INFLUENCE OF INITIAL POTASSIUM A-DV CONCENTRATION DIFFERENCE ON MAXIMAL INCREASE IN $\mathrm{K}$ A-DV PRODUCED BY INTRA-ARTERIAL INsulin. Data from 13 normal subjects who received insulin, $100 \mu \mathrm{U}$ per $\mathrm{kg}$ per minute, are shown by $\bullet$, by which the indicated linear regression line was calculated $(1,2)$. Response in 9 subjects, to whom insulin, $10 \mu \mathrm{U}$ per $\mathrm{kg}$ per minute, was administered, indicated by $\triangle$. 


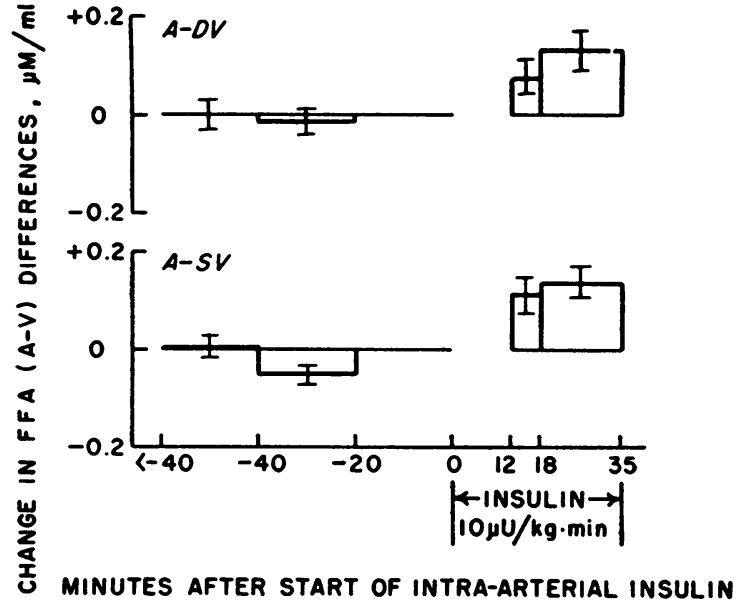

Fig. 5. EFfect of intra-Arterial insulin on FFA A-V Differences in 9 NORMal subJects. Data plotted as in Figure 2. by ten times the rate of insulin infusion. The change in $\mathrm{a}-\mathrm{dv}$ differences was greater than observed previously in the presence of $100 \mu \mathrm{U}$ per minute of insulin. This result is attributable to the more negative a-dv FFA differences in the current series. If insulin can do no more than obliterate FFA release, and if both rates of infusion of insulin prevented FFA output completely, the change in a-dv differences would be determined solely by the initial a-dv difference, which may have been the case.

The time courses of a-v glucose and FFA differences in 3 subjects in whom insulin was infused for 35 minutes appear in Figure 6 . To demonstrate that this dose of insulin modified glucose uptake is impossible, but FFA release was reduced in all. There was a similar uniform demonstration of $\mathrm{K}$ uptake.

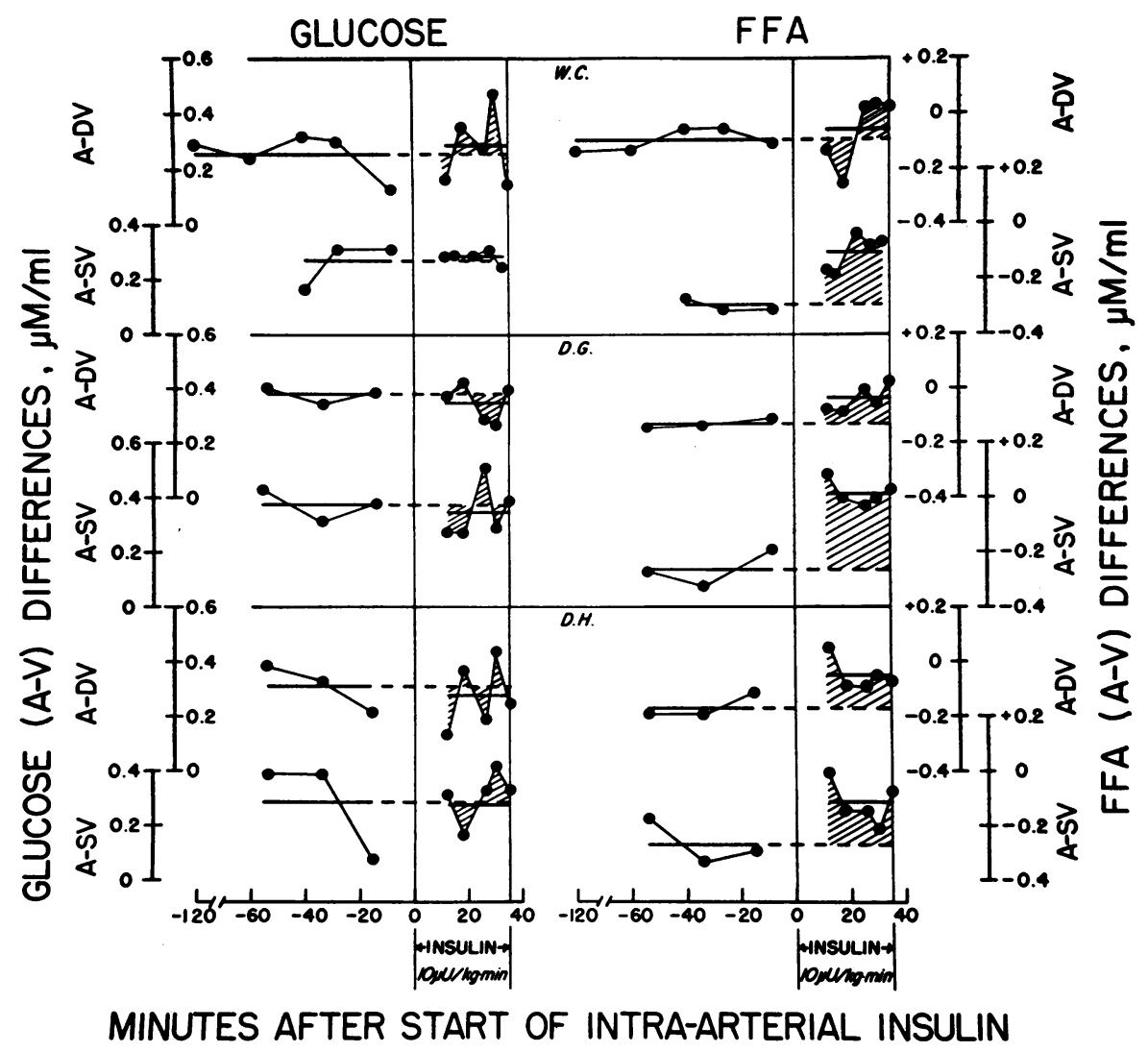

Fig. 6. Time course of a-v glucose and FFA differences in 3 subjects to whom INSULIN WAS ADMINISTERED FOR 35 MINUTES. The unbroken lines are mean a-v differences before and during insulin. In every case the mean basal a-v difference has been projected as a broken line. Insulin reduces FFA release but does not increase glucose uptake by deep or superficial forearm tissues. 


\section{Discussion}

When insulin is infused at constant rate into the brachial artery so as to exert no measured systemic effects, it has the following effects on forearm metabolism. When brachial arterial plasma insulin concentration is raised by about 4 $\mu \mathrm{U}$ per $\mathrm{ml}$, there are no effects; when it is raised by about $40 \mu \mathrm{U}$ per $\mathrm{ml}$, there is decreased release of FFA from forearm adipose tissue, and there is uptake of $\mathrm{K}$ by forearm muscle and adipose tissue without evidence of altered translocation of glucose; when it is raised by about $400 \mu \mathrm{U}$ per ml, there may be further block of FFA release, greater uptake of $\mathrm{K}$ by both muscle and adipose tissue, a fifteenfold increase in glucose uptake by muscle, and about a sixfold increase in glucose uptake by adipose tissue $(1,2)$. These observations are summarized in the dose-response curves (Figures 7 and 8).

Actions of insulin on release of FFA and on uptake of $\mathrm{K}$ by both forearm muscle and adipose tissue are much more apparent at a low dose than is its action on glucose; insulin probably achieves nearly its maximal effect on FFA and on $\mathrm{K}$ movements at small concentrations com-

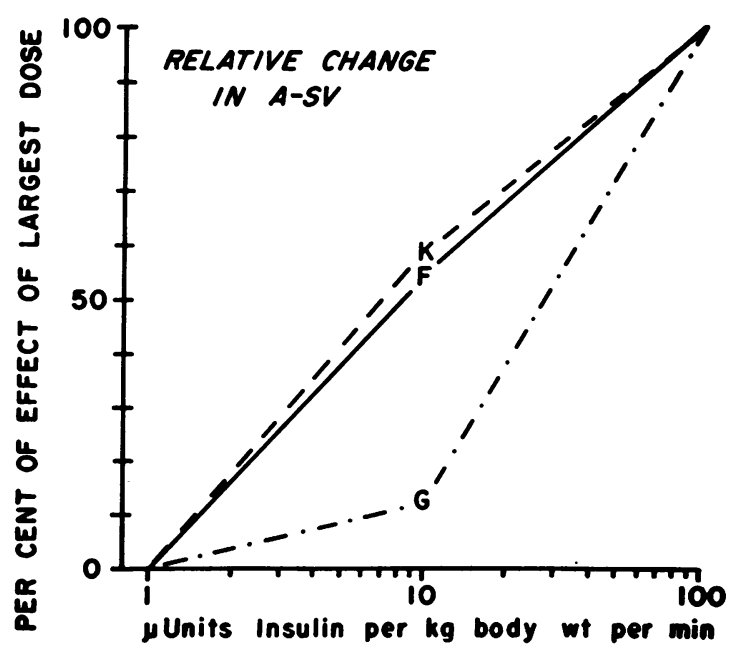

Fig. 7. Dose-Response curves. Effect of insulin on metabolism of tissues drained by a superficial vein, a-sv difference in response to infusion of $100 \mu \mathrm{U}$ per $\mathrm{kg}$ per minute set at $100 \%$. Data on FFA indicated by $\mathrm{F}$, on $\mathrm{K}$ by $\mathrm{K}$, on glucose by G. Approximate brachial arterial insulin concentration achieved with indicated infusion rates can be determined from the fact that the lowest rate produced a concentration of about $4 \mu \mathrm{U}$ per ml. See text for details.

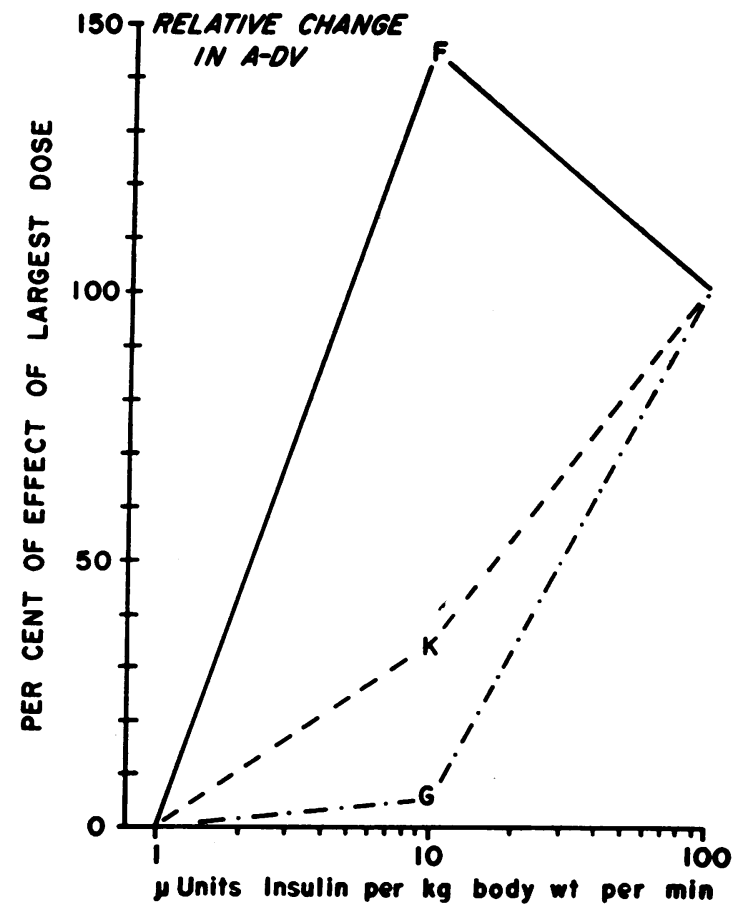

Fig. 8. DOSE-RESPONSE CURVES. Effect of insulin on metabolism of tissues drained by the deep vein. See legend to Figure 7.

pared to the concentration at which it reaches its maximal effect on glucose movement. It may be significant in regard to mechanisms by which the pancreas is stimulated to discharge insulin that an increment of $40 \mu \mathrm{U}$ of insulin per ml of plasma is less than that produced endogenously in man in response to a glucose load (11); that is, when elevated arterial glucose concentration is the stimulus for insulin release, it provokes the release of enough insulin to translocate glucose into cells, and $40 \mu \mathrm{U}$ per $\mathrm{ml}$ is inadequate for this task. These facts suggest that a fruitful inquiry might be made into effects of altered plasma $\mathrm{K}$ or FFA concentrations as modifiers of discharge of insulin from the pancreas.

Langs and Andres (12) reported in abstract form that forearm muscle glucose uptake increased by $0.94 \mu$ mole per minute per $100 \mathrm{ml}$ of forearm, measured as the product of blood flow and a-dv glucose differences, when brachial arterial plasma was augmented by about $40 \mu \mathrm{U}$ per ml. We have no explanation for what is in fact a small difference in quantitative observation between our two laboratories, but we are agreed 
that the response with respect to glucose is small or absent compared to the larger response with respect to $\mathrm{K}$ and FFA.

Our observations show that tissues drained by deep veins are about as sensitive to insulin with respect to $K$ uptake as are those forearm tissues drained by superficial veins, and that both sets of tissues are about equally insensitive with respect to glucose uptake. Difference in insulin responsiveness does not appear to lie in the responding tissue, as has been suggested by reports that an inhibitor impedes the action of insulin on excised muscle but not on excised adipose tissue (13-16). From measurements of forearm metabolism, the difference in sensitivity resides in the mechanism by which glucose is translocated, whether in muscle or in adipose tissue, compared to the mechanism by which $\mathrm{K}$ is translocated, whether in muscle or in adipose tissue.

Because an effect of insulin on glucose uptake cannot be demonstrated under conditions in which an effect on $\mathrm{K}$ uptake and on FFA release can easily be demonstrated, it is difficult to avoid the conclusion that actions of insulin on FFA release and on $\mathrm{K}$ uptake are independent of translocation of glucose.

On the basis of the different time courses of the effects of insulin, infused at $100 \mu \mathrm{U}$ per minute, on $\mathrm{K}$ and on glucose a-dv differences in the fore$\mathrm{arm}$, it was suggested previously that the effect of insulin on $\mathrm{K}$ was independent of its effect on glucose (1). This suggestion is supported by observations on excised rat skeletal muscle in which insulin hyperpolarized membranes (17) and decreased $\mathrm{K}$ efflux (18) even when glucose was absent from the bathing solution.

We have also suggested, from observations of persistent inhibition of FFA release with diminished effect on glucose uptake by forearm adipose tissue exerted by insulin in the presence of growth hormone $(3,4,6,7)$, that the effect of insulin on FFA release may be independent of glucose uptake by adipose tissue. We repeat this suggestion, now buttressed by the observation that infusion of insulin at $10 \mu \mathrm{U}$ per minute obliterated completely a-sv FFA difference but failed to alter glucose uptake by forearm adipose tissue within the limits of our ability to resolve the measurement. There is now support for this suggestion in observations by Jungas and Ball (19) and by
Mahler, Tarrant, Stafford, and Ashmore (20) made on excised segments of rat epididymal fat pads incubated in the absence of glucose.

The suggestion that the process by which insulin reduces release of FFA from adipose tissue is independent of glucose uptake is at odds with what may be the generally held current view. A re-examination of the basis for the widely accepted view may help place matters in perspective.

Hirsch, Lossow, and Chaikoff (21) may have turned attention to a relation between glucose metabolism and FFA release by their report that glucose enhanced esterification of fatty acids by slices of rat mammary gland. Wertheimer and Shafrir (22) seem to have been the first to enunciate the hypothesis publicly, although it may have been in the wind since it was spelled out almost simultaneously by three other groups during 1960. The hypothesis that Wertheimer and Shafrir proposed but did not support with any data was that glucose is dissimilated in part to $\alpha$ glycerophosphate, that newly synthesized fatty acids and fatty acids newly liberated from triglycerides are esterified or re-esterified by combining with $\alpha$-glycerophosphate, and that the newly formed triglyceride cannot diffuse out of adipose tissue but remains as added stored fat, whereas, had esterification or re-esterification not taken place, FFA would presumably have passed out of adipose tissue into either the bathing solution or interstitial fluid. "The process of esterification may be entirely dependent on the supply of glucose-derived glycerol and thus extremely sensitive to changes in the breakdown of this substrate" (22).

Raben and Hollenberg (23) may have been first to propose that the mechanism by which insulin reduces release of FFA from adipose tissue was simply that insulin increased glucose uptake and that "the metabolism of carbohydrate may restrict the output of free fatty acids by adipose tissue by promoting esterification and thus limiting the accumulation of free acid within the tissue." The data, however, do not lead inevitably to the hypothesis. The observations were only that there was less titratable fatty acid extracted from rat epididymal fat pads after 3-hour incubation in a medium containing glucose or glucose and insulin than in one free of glucose. When the concentration of glucose in the medium was 
100 or $200 \mathrm{mg}$ per $100 \mathrm{ml}$, there was no effect on FFA disappearance compared to that observed in the absence of glucose. Not until the concentration of glucose in the bath was $400 \mathrm{mg}$ per $100 \mathrm{ml}$ may there have been an effect of glucose alone, but even this is uncertain because this observation rests only on determinations made on fat pads from 3 rats and only the mean values were presented. Insulin alone, in the absence of glucose, had no effect on tissue fatty acid content. Clearly, however, in fat pads (from 2 groups of 3 rats) bathed in glucose, $200 \mathrm{mg}$ per $100 \mathrm{ml}$, plus insulin (stated only as " $10 \mathrm{mU}$," with no notation of the unit volume), there was less titratable fatty acid than in the absence of glucose and insulin. The sum of these observations, which are difficult to assess because they were distributed among a number of variable experimental conditions each of which was, in general, examined to only a small degree ( 5 groups of 2 rats each, 3 groups of 2 rats each), seems to be that the combination of glucose and insulin may leave less titratable fatty acid in the system, medium plus tissue, than in the absence of either or both, but this observation alone is subject to explanations other than that proposed by the authors.

This report was followed by an independent formulation of the hypothesis in a preliminary communication by Steinberg, Vaughan, and Margolis (24). Although it was entitled "Control of Fatty Acid Release from Adipose Tissue through Control of the Rate of Triglyceride Synthesis," the experiments were restricted to measurement of $\mathrm{C}^{14}$ in neutral lipids in adipose tissue after incubation of fat pads in a solution containing palmitate-1-C ${ }^{14}$. Glucose was said to increase, and epinephrine and ACTH to decrease, radioactivity in neutral lipids. Insulin was not studied. The number of observations was small, only 2 or 3 per group, except that there were 6 in the epinephrine group, and data, even if confirmed by further experience, do not point unequivocally to re-esterification.

In the same year, 1960, a more thorough study by Bally, Cahill, Leboeuf, and Renold appeared (25), also advancing the esterification hypothesis. Although the number of observations was substantial, their interpretation is awkward owing in large part to the method of calculation and to the fact that only radioactivity was determined, and this only at the end of a fixed period of incubation. The experiments consisted of incubation of rat epididymal fat pads in a solution containing palmitate-1- $\mathrm{C}^{\mathbf{1 4}}$ for 3 hours. Radioactivity was determined in $\mathrm{CO}_{2}$ and in various tissue lipid fractions, but the total quantity of mother substance in these fractions was not determined. Although what was measured was radioactivity, all data were "expressed as microequivalents of fatty acid (calculated from the counts per milliliter and the titratable fatty acids per milliliter at the beginning of the incubation) recovered in the tissue lipid fraction or in the evolved $\mathrm{CO}_{2}$ at the end of incubation." This suggests that the counts per minute observed at the end of the experiment was divided by the initial specific activity of the bathing solution. If this is what was done, the results are at best evidence only of incorporation of label in the metabolite measured. They do not distinguish among changes in rates at which reactions proceeded or changes in the sizes of the various pools through which the label was distributed.

What is lacking are data in which changes in pool size and in specific activity of various metabolites are measured as functions of time until either a steady state is reached or, in the absence of this, until the experiment must be terminated for practical reasons.

The substance of the support for the re-esterification hypothesis is, therefore, slim. Although the hypothesis may be plausible and although it may even eventually be demonstrated that dissimilation of glucose results in net esterification of fatty acids, none of the experiments demonstrate that the mechanism whereby insulin exerts its effect (the striking reduction or obliteration of FFA release from adipose tissue) is secondary to enhanced dissimilation of glucose to $\alpha$-glycerophosphate with consequent trapping of fatty acids within adipose tissue.

The question arises as to whether or not the small, but not statistically significant, change in glucose a-sv difference might be adequate to provide sufficient $\alpha$-glycerophosphate for re-esterification of intracellular FFA in an amount that would account for the observed decrease in a-sv FFA of $0.14 \mu$ mole per ml (Table III). Since each molecule of glucose provides sufficient carbons for 2 molecules of $\alpha$-glycerophosphate and since both molecules of $\alpha$-glycerophosphate can com- 
bine with 3 molecules of fatty acid, we begin the calculation by dividing 0.14 by 6 to yield 0.023 . But FFA transfer is only between plasma and cells, whereas glucose transfer is between whole blood and cells. Therefore, 0.023 is multiplied by the so-called plasmacrit, about 0.55 , to yield 0.013 . If every molecule of glucose translocated from blood into adipose cells were dissimilated to $\alpha$-glycerophosphate, then an increase in a-sv glucose difference of $0.013 \mu$ mole per $\mathrm{ml}$ would suffice to explain the observed decrease in FFA release, if the re-esterification hypothesis were correct. This is a quantity beyond the resolution of our method. To put it in perspective, arterial glucose concentration is $5 \mu$ moles per $\mathrm{ml}$ or 385 times an a-v difference of $0.013 \mu$ mole per ml.

There are, however, no data suggesting that glucose is dissimilated in adipose tissue only to $\alpha$-glycerophosphate. Lynn, MacLeod, and Brown (26) reported that, whether the glucose in the bathing solution was labeled in the 1 or in the 6 position, less than $10 \%$ of the glucose uptake appeared in the glycerol fraction of adipose tissue triglyceride, whether there was no insulin or whether there was either of two concentrations of insulin in the bathing solution. Cahill, Leboeuf, and Renold (27) reported related experiments. From their data, obtained when epididymal fat pads were incubated with uniformly labeled glucose without insulin, we can calculate that $44 \%$ of the $\mathrm{C}^{14}$ that was recovered (total percentage of recovery was not given) appeared in the glycerol fragments from glycerides. Although they gave no data on the effect of insulin when the medium contained glucose- $\mathrm{U}-\mathrm{C}^{14}$, their experience with adipose tissues incubated with insulin and with either glucose-1-C ${ }^{14}$ or glucose-6-C ${ }^{14}$ substantiates the observations of Lynn, MacLeod, and Brown (26). When epididymal fat pads were incubated in a solution containing $5 \mathrm{mM}$ glucose and $0.1 \mathrm{U}$ of insulin per $\mathrm{ml}$ of the extra $\mathrm{C}^{14}$ recovered in response to insulin (which is the datum desired to compare this with results of forearm experiments), only $5 \%$ appeared as glyceride-glycerol.

If we assume that as much as $10 \%$ of the glucose taken up in response to insulin is converted to $\alpha$-glycerophosphate, then to account for the observed change in a-sv FFA by this hypothesis there would be required an increase in a-sv glu- cose difference of $0.13 \mu$ mole per $\mathrm{ml}$. This is an increase almost twice the observed mean increase in a-sv glucose (Table III) and exceeding the observed mean increase by 1.3 standard errors of the mean. Analysis of data from individual subjects (Table III) reveals that in the first 3 subjects the observed glucose a-sv was sufficient to account for the decreased a-sv FFA difference on the basis of the re-esterification hypothesis and that in the last 6 subjects it was not adequate. Among the last 3 subjects, who received insulin for 35 minutes and from whom there are more data, mean change in glucose a-sv during the period 19 to 35 minutes after onset of insulin infusion was zero, and mean change in a-sv FFA was $0.15 \mu$ mole per $\mathrm{ml}$.

The odds are therefore against the re-esterification hypothesis as an explanation of insulin's action on FFA release from forearm adipose tissue. An alternative hypothesis for the action of insulin on FFA release may arise from the following.

Since there is evidence that insulin acts on the membrane of skeletal muscle to produce a rapid change in $\mathrm{K}$ flux (18) and to increase the electrical potential difference across the membrane of resting skeletal muscle $(17,28)$, it has been proposed that insulin combines with the membrane, changing the fixed charge in the membrane and at the same time warping it to increase its permeability to glucose (29). From the effects of insulin on forearm metabolism, we suggest that less insulin is required to alter the fixed charge than to increase its permeability to uncharged particles.

Beigelman and Hollander (30) report that cells of excised rat epididymal fat pads are also hyperpolarized by insulin, whether or not glucose is in the bathing solution. This suggests that insulin combines with adipose cell membrane as it has been proposed to do with muscle. If there is to be a unitary hypothesis concerning the mechanism of insulin's action, apparently it must include the combination of insulin with membranes of susceptible cells, and to this end it is appropriate to propose that insulin's blockade of FFA release may prove to be by this mechanism. We are now investigating the kinetics of FFA movement into and out of adipose cells and the effect of insulin on these rates. 


\section{Summary}

Insulin was given by constant infusion into the brachial artery, and its effect on forearm muscle and adipose tissue was assessed by measuring arterial, deep venous, and superficial venous concentrations of glucose, potassium, and free fatty acids. None of the doses of insulin caused any systemic effects as determined by constant arterial concentrations of glucose, $\mathrm{K}$, and FFA.

Infusion of insulin at a rate of $1 \mu \mathrm{U}$ per minute per $\mathrm{kg}$ body weight had no effect.

Insulin infused at $10 \mu \mathrm{U}$ per $\mathrm{kg}$ per minųte (enough to raise brachial arterial plasma insulin concentration by an average of $38 \mu \mathrm{U}$ per $\mathrm{ml}$ ) markedly increased $\mathrm{K}$ uptake by forearm tissues drained by either deep or superficial vein and sharply reduced FFA release from adipose tissue. This dose could not be shown to have any effect on glucose uptake by any tissue drained by the forearm veins sampled.

We conclude that insulin's actions on $\mathrm{K}$ uptake and on FFA release do not require that insulin translocate glucose, and we propose that these actions of insulin may be explained on the basis of interaction between insulin and the cell membrane.

\section{Acknowledgments}

We are indebted to those who volunteered for these experiments and to Mrs. Ronald Isaacs, Misses Louise Margolet and Ellen Rogus, and Mr. William J. Sullivan for technical assistance.

\section{References}

1. Andres, R., M. A. Baltzan, G. Cader, and K. L. Zierler. Effect of insulin on carbohydrate metabolism and on potassium in the forearm of man. J. clin. Invest. 1962, 41, 108.

2. Rabinowitz, D., and K. L. Zierler. Role of free fatty acids in forearm metabolism in man, quantitated by use of insulin. J. clin. Invest. 1962, 41, 2191.

3. Rabinowitz, D., and K. L. Zierler. Dissociation of insulin action in the forearm of man (abstract). J. clin. Invest. 1962, 41, 1393.

4. Rabinowitz, D., and K. L. Zierler. Preservation of insulin effect on FFA movement in hypophysealadrenocortical dependent insulin resistance (abstract). Physiologist 1962, 5, 197.

5. Rabinowitz, D., and K. L. Zierler. A metabolic regulating device based on the actions of human growth hormone and of insulin, singly and to- gether, on the human forearm. Nature (Lond.) 1963, 199, 913.

6. Rabinowitz, D., and K. L. Zierler. Differentiation of active from inactive acromegaly by studies of forearm metabolism and response to intra-arterial insulin. Bull. Johns Hopk. Hosp. 1963, 113, 211.

7. Zierler, K. L., and D. Rabinowitz. Independence of insulin action on potassium and on fatty acids from its action on glucose. Trans. Ass. Amer. Phycns 1963, 76, 245.

8. Andres, R., G. Cader, and K. L. Zierler. The quantitatively minor role of carbohydrate in oxidative metabolism by skeletal muscle in intact man in the basal state. Measurements of oxygen and glucose uptake and carbon dioxide and lactate production in the forearm. J. clin. Invest. 1956, 35, 671.

9. Baltzan, M. A., R. Andres, G. Cader, and K. L. Zierler. Heterogeneity of forearm metabolism with special reference to free fatty acids. J. clin. Invest. 1962, 41, 116.

10. Rabinowitz, D., and K. L. Zierler. Forearm metabolism in obesity and its response to intra-arterial insulin. Characterization of insulin resistance and evidence for adaptive hyperinsulinism. J. clin. Invest. 1962, 41, 2173.

11. Yalow, R. S., and S. A. Berson. Immunoassay of endogenous plasma insulin in man. J. clin. Invest. $1960,39,1157$.

12. Langs, $H$., and R. Andres. Insulin sensitivity of peripheral tissues in man (abstract). Fed. Proc. 1963, 22, 443.

13. Steinke, J., K. W. Taylor, and A. E. Renold. Insulin and insulin antagonists in the serum of untreated juvenile diabetes. Studies with isolated rat diaphragm and rat adipose tissue. Lancet 1961, 1,30 .

14. Vallance-Owen, J., and M. D. Lilley. An insulin antagonist associated with plasma-albumin. Lancet 1961, 1, 804.

15. Lowy, C., G. Blanshard, and D. Phear. Antagonism of insulin by albumin. Lancet 1961, 1, 802.

16. Stein, M., and D. M. Kipnis. Differential response of adipose tissue to insulin (abstract). Clin. Res. 1963, 11, 229.

17. Zierler, K. L. Hyperpolarization of muscle by insulin in a glucose-free environment. Amer. J. Physiol. 1959, 197, 524.

18. Zierler, K. L. Effect of insulin on potassium efflux from rat muscle in the presence and absence of glucose. Amer. J. Physiol. 1960, 198, 1066.

19. Jungas, R. L., and E. G. Ball. Studies on the metabolism of adipose tissue. XII. The effects of insulin and epinephrine on free fatty acid and glycerol production in the presence and absence of glucose. Biochemistry 1963, 2, 383.

20. Mahler, R., M. E. Tarrant, W. S. Stafford, and J. Ashmore. Antilipolytic effects of insulin. Diabetes 1963, 12, 359 . 
21. Hirsch, P. F., W. J. Lossow, and I. L. Chaikoff. Effect of glucose on fatty acid and glyceride synthesis in rat mammary gland. J. biol. Chem. 1956, 221, 509.

22. Wertheimer, E., and E. Shafrir. Influence of hormones on adipose tissue as a center of fat metabolism. Recent Progr. Hormone Res. 1960, 16, 467.

23. Raben, M. S., and C. H. Hollenberg. Effect of glucose and insulin on the esterification of fatty acids by isolated adipose tissue. J. clin. Invest. 1960, 39, 435.

24. Steinberg, D., M. Vaughan, and S. Margolis. Control of fatty acid release from adipose tissue through control of the rate of triglyceride synthesis. J. biol. Chem. 1960, 235, PC 38.

25. Bally, P. R., G. F. Cahill, Jr., B. Leboeuf, and A. E. Renold. Studies on rat adipose tissue in vitro. V. Effects of glucose and insulin on the metabolism of palmitate-1-C ${ }^{14}$. J. biol. Chem. 1960, 235, 333.
26. Lynn, W. S., R. M. MacLeod, and R. H. Brown. Effects of epinephrine, insulin, and corticotrophin on the metabolism of rat adipose tissue. J. biol. Chem. 1960, 235, 1904.

27. Cahill, G. F., Jr., B. Leboeuf, and A. E. Renold. Factors concerned with the regulation of fatty acid metabolism by adipose tissue. Amer. J. clin. Nutr. 1960, 8, 733.

28. Zierler, K. L. Effect of insulin on membrane potential and potassium content of rat muscle. Amer. J. Physiol. 1959, 197, 515.

29. Zierler, K. L. A model of a poorly-permeable membrane as an alternative to the carrier hypothesis of cell membrane penetration. Bull. Johns Hopk. Hosp. 1961, 109, 35.

30. Beigelman, P. M., and P. B. Hollander. Effect of insulin upon resting electrical potential of adipose tissue. Proc. Soc. exp. biol. (N. Y.) 1962, 110, 590. 